\title{
Biometric Enabled Ration Card Security System for Public Distribution System
}

\author{
Laxman Kumarwad ${ }^{1}$, Rajendra Kumbhar ${ }^{2}$ \\ Assistant Professor, Department of MCA, Government College of Engineering, Karad, India ${ }^{1}$ \\ Assistant Professor, Department of Systems Management, KBP IMSR, Satara, India ${ }^{2}$
}

\begin{abstract}
This paper is proposed the improvised technique of implementing smart ration card. Currently, ration card is very useful to every household for various purposes such as family member's details, to get subsidized food items and non-food items, gas connection, and also address proof for various purposes. All people having a ration card to get different foodgrain items such as sugar, rice, wheat and non-food items like edible oils and kerosene from fair price shops. But our public distribution system having many drawbacks like all customer details stored in manually in the registers. This may cause to pilferage. Because of security issues, the ration cards are duplicated by the middlemen, so using computerized ration cards can reduce the misuse and frauds. This article proposed biometric fingerprint system implementing security futures in ration cards so it will bring transparency in the public distribution system.
\end{abstract}

Keywords: Biometric Fingerprint, Fingerprint Classification, PDS.

\section{INTRODUCTION}

India's Public Distribution System (sarvajanik vitaran initiative by Government of India as Mission Mode pranali) is the largest distribution system in the world. Project [6]. Laxman L. Kumarwad, Rajendra D. Kumbhar This system distributes subsidized food grains and non- [7] these researchers proposed the linkage between the foods item to the beneficiaries. Government of India biometric fingerprints, GPS and UID with the PDS. purchase the foodgrains item from the open market through the Food Corporation of India and distributes to the needy citizens on subsidized prices through the Fair Price Shop. Currently, this system having a huge pitfalls in distribution of the subsidized items. Because all the system is manual. There is no security futures in the issuing the rationa card. Several reports are published on PDS by the Government of India.

\section{LITERATURE REVIEW}

In recent days Vikram et.al. has proposed smart ration card system. The Smart card is modified as smart ration card by using microprocessor chip. In that smart card contains a unique barcode, when the customer visits the FPS then our card firstly check through the barcode reader. Dealer verifies the smart card and issues the commodities [1]. Also S.Valarmathy et.al. [2], Mohan et. al. [3] and Sukumar et. al. has [4] proposed an automatic ration commodities distribution based on Global System Mobility (GSM) and Radio Frequency Identification (RFID) technology. In this system, provides commodities without the interference of human and measure commodities items using sensors. Kashinath has proposed a simple Personal Digital Assistant (PDA) device and RFID tag ration card. PDA device is similar to ticketing machine used by bus conductor or bank pigmy agent and our card is similar to the swipe card. The customer can use swipe card instead of ration card and get commodities of the shop [5]. PDS is come under e-governance project

\section{EXISTING SYSTEM}

The present day's public distribution system used ration card of each family and all records stored manually in the book of ration shop. For getting the food or non-food items from the fair price shop (FPS), first, the beneficiaries need to produce the ration card and put the signature in the ration card. Then the FPS shopkeeper will issue the items through weighting system. But in this the manual system having two drawbacks, first one is the weight of the items may be inaccurate due to human mistakes and secondly, if the beneficiaries not approached to the FPS, the shopkeeper will sale the remaining items in the open market on a higher rate..

\section{A. Drawbacks in Existing System}

- Identification of poor by the states is not fool proof. A large number of poor and needy persons are left out and a lot of fake cards are also issued [8].

- Retail Shop uses fake Ration cards and sells the food grains in the black market.

- People do not get the allotted amount of food grains from the shop.

Sometimes, good quality food grains are replaced with poor quality cheap food grains.

- The PDS includes only few food grains such as wheat and rice, it does not fulfill the requirement of complete nutrition [8]. 
IARJSET

- The irregular distribution of food generations, commodities of ration shops and distribution for him. One procurement, and distribution. For example, northern time registration is allowed per user. states are very far from Kerala from where rice is procured. To transport food grains from Kerala to farflung areas in Northern states will entail cost and time both.

- Many times there are cases that ration cards are fake or using dead people ration card or multiple ration cards.

\section{PROPOSED SYSTEM}

The main purpose of the Secure Ration Card System is to reduce the paperwork involved, widespread corruption, misuses of cards and duplications of ration cards. To reduce the time complexity of the manual data entries and checks. Many fake ration card users exist which is against the law, it helps to curb these things. Our system is used to protect the products of FPS in black markets. This system mainly focuses on designing and implementation of a security system for a ration card using fingerprint that has been used to the at FPS of Civil Supply Corporation. In recent scenarios, can get fingerprint using the biometric device and it is the science of verifying the identity of an individual through physiological measurements or behavioral traits. Since biometric identifiers are associated permanently with the user they are more reliable than token or knowledge based authentication methods [9]. Biometrics offers several advantages over traditional security measures. All public and private sectors using smart card systems to provide security [10]. Still, it is not up to the security level, this system overcomes that problem by using biometric device for the Civil Supply Corporation.

All the public sectors distribute the products to all the citizens. There are various commodities like wheat, rice, sugar and kerosene which are distributed using conventional ration shops. Here the family members need to register with their finger prints to get the unique family identification by using this unique ID. The family members can access the commodities and access control will be provided for the family members and the administrator. Only an authorized person can access the system. The main objective of the systems is to provide security and transparency of authorization allocations of commodities equally to all needy and economical poor citizens of India. Architecture of the biometric based ration card security system shown in fig. 1 .

\section{A. System Features}

- Easy to use:

This system provides a user friendly interface to users, its means anyone can easily use this system even for those who have very less knowledge about computer and how to use it.

- Secure process:

Each customer will know the exact prices of commodities which are fixed by the government and cannot be changed by the shopkeeper. The customer must know all the

- Easy access and storage of records:

The shopkeeper can store records easily and do less paperwork and access all the previous details anytime.

- Reduce time:

Here we are using fingerprint technique [10], which helps in reducing the time complexity at the time of matching image and searching the particular person's fingerprint from a database to check whether the person is registered or not.

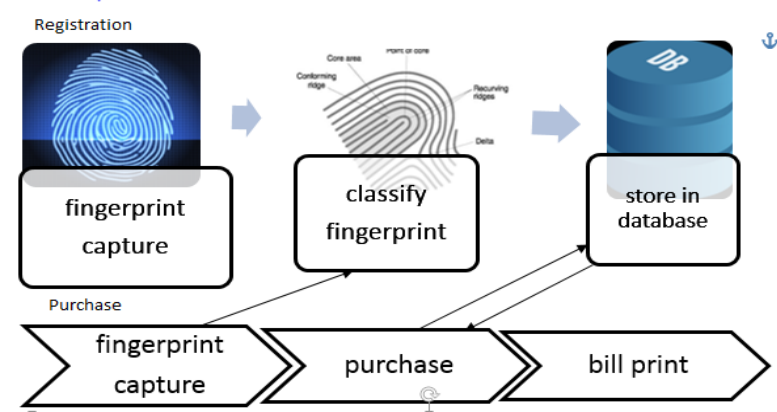

Fig. 1 Architecture of Biometric based Ration Card Security System.

\section{B. System Process}

- Registration:

First, the registration process includes capturing the fingerprint from the customer and asking required information as shown in fig. 2.

- Fingerprint Classification:

After getting the fingerprint image it is classified according to the minute points present on it. After this, the fingerprint image is stored in a particular database.

- Purchase:

When the customer comes to purchase any commodity he will be asked to the fingerprint which will be again classified and compared with the database.

- Bill Print:

After the successful match, the commodity will be given to the customer.

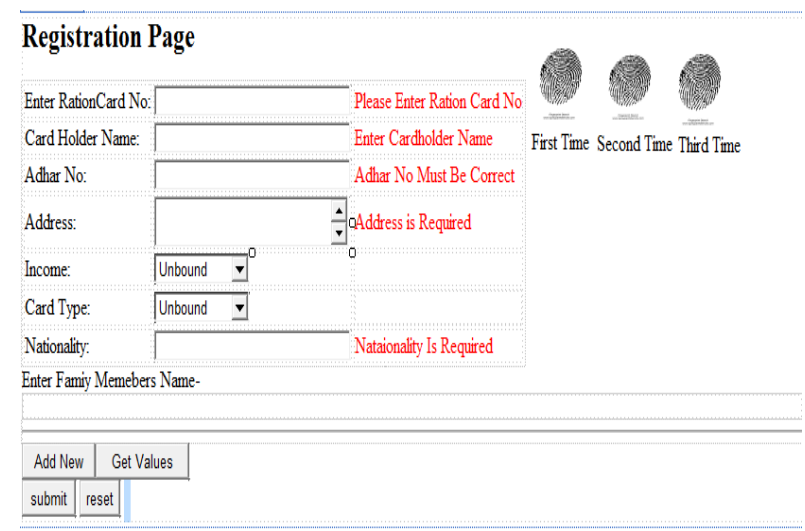

Fig. 2 Registration form for customers. 
IARJSET

\section{CONCLUSION}

To overcome the issues, utilization of a technology which linkage of UID with the PDS, use of biometric enabled smart cards for the beneficiary identification. There must be a Public Private Partnership (PPP) to develop the system. The government also needs to check the efficiency and effectiveness of the system from the private agencies.

Using this proposed biometric enabled fingerprint management system can have managed better ways of ration card system to stop the pilferage of the commodities. Also, the computerized ration system to achieve paperless work and to increase security and using this system, can achieve transparency and reduce sales of commodities in the black market.

\section{ACKNOWLEDGMENT}

We express our sincere thanks to all authors, whose articles published in the area of e-governance in various conference proceedings and journals. Our special thanks to Prof. Subhash Bhatnagar, Indian Institute of Management, Ahmedabad for their work on e-governance published in various conferences and journals.

\section{REFERENCES}

[1] Vikram Singh et. al. "Smart ration card", Volume 4, No. 4, April 2013 Journal of Global Research in Computer Science.Tavel, P. 2007 Modeling and Simulation Design. AK Peters Ltd.

[2] S.Valarmathy et. al. "Automatic ration material distribution based on GSM and RFID technology", I.J. Intelligent Systems and Applications, 2013, 11, 47-54 published Online October 2013 in MECS.

[3] Mohan et. al. "Automation of ration shop using PLC." VoI.3, Issue.5, SeptOct 2013. International Journal of Modern Engineering Research.

[4] Sukhumar et. al. "Automatic Rationing System Using Embedded System Technology", volume 1 Nov 2013, International Journal of Innovative Reserch in Electrical, Electronics, Instrumentation and Controle Engineering.

[5] Kashinath Wakade "Smart Ration Distribution and Controlling" International Journal of Scientific and Research Publications, Volume 5, Issue 4, April 2015.

[6] I.J. Information Engineering and Electronic Business, 2016, 5, 18 25 Published Online September 2016 in MECS (http://www.mecspress.org/) DOI: 10.5815/ijieeb.2016.05.03.

[7] Laxman L. Kumarwad, Rajendra D. Kumbhar,"E-Governance Initiatives in Maharashtra (India): Problems and Challenges", International Journal of Information Engineering and Electronic Business(IJIEEB), Vol.8, No.5, pp.18-25, 2016. DOI: 10.5815/ijieeb.2016.05.03

[8] http://www.civilserviceindia.com/subject/GeneralStudies/notes/public-distribution-system-functioning-limitationsrevamping.html

[9] http://ethesis.nitrkl.ac.in/4360/1/A_study_on_Fingerprinti mage_Enhancement_and.pdf

[10] Fingerprint Classificationwww.cse.msu.edu/biometrics/Publications/Fingerprint/clas.pdf

\section{BIOGRAPHIES}

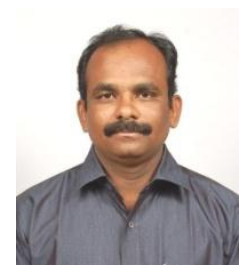

Laxman L. Kumarwad, Assistant Professor in Master of Computer Application Department at Government College of Engineering, Karad, Maharashtra in India. He is pursued MCA degree from University of Pune, India and now pursuing Ph.D. in Computer Application from Shivaji University, Kolhapur, India. He has 8 years of teaching experience at Post Graduate level. His research activities include eGovernance, ICT.

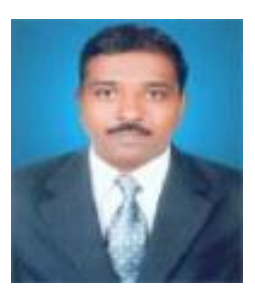

Dr. Rajendra D. Kumbhar, Assistant Professor in System Management Department of Karmveer Bhaurao Patil Institute of Management Studies and Research, Satara, Maharashtra, India. He is pursued MCA, Ph.D. Computer Application from Shivaji University, Kolhapur. He has 16 years of Teaching experience in System Management for UG and PG. His research area is e-Governance, ERP. He has published 22 research articles in refereed journal. 